\title{
PRUNING OPERATION IN URBAN TREES USING TWO AERIAL WORK PLATFORMS
}

\author{
Oscar Manuel de Jesús Vera Cabral ${ }^{1 *}$, Carla Krulikowski Rodrigues ${ }^{2 *}$, Hugo Armando Barúa Acosta ${ }^{1}$, Juan José \\ Bonnin Acosta ${ }^{1}$, Eduardo da Silva Lopes ${ }^{3}$ \\ 1* Universidad Nacional de Asunción, Facultad de Ciencias Agrarias, Asunción, Paraguay - oscar.vera@agr.com.py *; \\ hugo.barua@agr.una.py; jose.bonnin@agr.una.py \\ ${ }^{2}$ Universidade Federal do Paraná, Departamento de Ciências Florestais, Curitiba, Paraná, Brasil - carlakr@ gmail.com \\ ${ }^{3}$ Universidade Estadual do Centro-Oeste, Programa de Pós-Graduação em Ciências Florestais, Irati, Paraná, Brasil - eslopes@ unicentro.br
}

Received for publication: 17/11/2019 - Accepted for publication: 02/07/2020

\begin{abstract}
Resumo
Operação de poda em árvores urbanas usando duas plataformas de trabalho aéreo. A necessidade de reduzir riscos de acidentes e esforço físico dos trabalhadores na operação de poda urbana de árvores promove a busca de tecnologias com menor custo de execução. O objetivo foi avaliar o desempenho operacional da poda urbana de árvores com duas plataformas de trabalho aéreo realizadas em árvores de domínio público e privado na Grande Assunção, Paraguai. As plataformas de trabalho aéreo avaliadas foram: articulada e montada em caminhão, em três níveis de trabalho. Através de estudo de tempos e movimentos foram determinados tempos de ciclo de trabalho, eficiência operacional, consumo de combustível e custos operacionais. A amostragem consistiu em 78 árvores, nas quais os valores médios foram comparados entre os níveis de trabalho pelo teste de Tukey $(\alpha=0,05)$. O tempo de ciclo de trabalho mais longo consumido foi na poda sem movimento da base da máquina, com eficiência operacional média de 86,2 e 76,8\% na plataforma articulada e na plataforma montada em caminhão, respectivamente. O consumo de combustível aumentou com os níveis de trabalho e foi mais alto na plataforma montada em caminhão, de 7,33 para 9,33 $\mathrm{L} \mathrm{h}^{-1}$ de óleo diesel, a USD 18,93 por hora. Portanto, a plataforma articulada e a plataforma montada em caminhão avaliadas na poda urbana de árvores apresentaram diferentes custos operacionais que aumentaram com o maior nível de amplitude de movimento. O principal motivo foi a intensificação da operação do motor e os gastos de energia exigidos pelo sistema hidráulico das máquinas, especialmente na plataforma montada em caminhão.

Palavras-chave: arboricultura, tratamentos silviculturais, estudo de tempos e movimentos.
\end{abstract}

\section{Abstract}

The need to reduce accident risks and physical effort of workers in urban tree pruning operations promotes a search for technologies with less execution cost. In this context, the aim of this study was to evaluate the operational performance of urban tree pruning with two aerial work platforms conducted in trees under public and private domain in Greater Asunción, Paraguay. The aerial work platforms evaluated were an articulated boom lift and truck mounted boom lift in three working envelopes levels. Work cycle times, operational efficiency, fuel consumption, and operating costs were determined through a time and motion study. Sampling consisted of 78 trees in which the mean values between the working envelope levels were compared by the Tukey test $(\alpha=0.05)$. The longest consumed work cycle time was in pruning without machine base motion with a mean operational efficiency of 86.2 and $76.8 \%$ in the articulated boom lift and truck mounted boom lift, respectively. Fuel consumption increased with working envelope levels, and it was the highest in the truck mounted boom lift, from 7.33 to $9.33 \mathrm{~L} \mathrm{~h}^{-1}$ of diesel fuel, at USD 18.93 per hour. Therefore, the articulated boom lift and truck mounted boom lift evaluated in urban tree pruning presented different operating costs which increased with the highest range of motion level. The main reason for this was the engine operation intensification and energy expenditures required by the machines' hydraulic system, especially in the truck mounted boom lift.

Keywords: arboriculture, silvicultural treatments, time and motion study.

\section{INTRODUCTION}

Tree presence in the urban environment and its performed function are life quality indicators of the citizens (DOBBS et al., 2011; NATH et al., 2018). Therefore, pruning stands out as an important treatment to be performed for efficient management of this resource, since it presents different purposes and complex operations due to the tree particularities from the operational viewpoint (DUJESIEFKEN; STOBBE, 2002; FINI et al., 2015).

When performed on large trees, urban pruning requires skilled labor for aerial work (ZILLMER et al., 2000). In these conditions, it is necessary to adopt complex climbing practices in reduced environments when carried out without aerial work machines, along with a consequent high physical effort in this operation (VOGT et al., 2015). These aspects make urban tree pruning a highly specific, demanding, and expensive work.

The risk of accidents and workers' physical effort need to be reduced in pruning operations in order to preserve citizens integrity and buildings, as well as to reduce execution cost (FIEDLER et al., 2006; LEAL et al.,

FLORESTA, Curitiba, PR, v. 51, n. 2, p. 476-483 abril/jun 2021

Cabral, O. M. J. V. et.al.

ISSN eletrônico 1982-4688

DOI: $10.5380 /$ rf.v51 i2. 70228 
2008; VOGT et al., 2015). However, tree pruning is usually performed with tools, equipment, and machines which are devoid of ergonomic characteristics (LOPES et al., 2013). Thus, we highlight the need to improve work-related aspects to satisfy labor regulations, in addition to investment and technological levels available for pruning operations.

The need to innovate tree pruning management has stimulated using aerial work platforms (PARAGUAY, 2015). However, urban pruning is not the main purpose of designing and manufacturing these machines, since they are designed for the civil construction and electric energy sectors (PRIESTLEY et al., 2002). Therefore, their use is restricted by high costs, professionalized worker requirements, maintenance, and logistics. Nevertheless, evaluating machine performance is necessary for planning and management decision-making for urban tree pruning.

In this context, the present study aims to evaluate the operational performance and costs of urban tree pruning using two aerial work platforms: (1) an articulated boom lift, and (2) a truck mounted boom lift, aiming to optimize resources, reduce occupational risks, and increase urban tree management efficiency.

\section{MATERIAL AND METHODS}

This study was carried out in urban tree pruning operations located in residential areas in the metropolitan region of Greater Asunción, Paraguay (coordinates: 25 $16^{\prime} \mathrm{S}$ and $57^{\circ} 38^{\prime} \mathrm{W}$ ). The region's climate is classified as Cfa according to the Köppen system, with a mean temperature of $23{ }^{\circ} \mathrm{C}$, mean annual rainfall of $1,400 \mathrm{~mm}$, and relative humidity of $70 \%$ (KOTTEK et al., 2006).

Traditional urban tree species were evaluated in public domains such as sidewalks, parking lots, and squares, as well as in private places such as residences (VERDADE; SZELEST, 2013). These trees are classified as risky by means of their physical characteristics: height, crown size, branch extension, proximity to buildings, possibility of contact or fall, and other related conflict types (PARAGUAY, 2015).

Urban tree pruning operations were performed by a team with four workers: one supervisor and three trained and experienced operators equipped with tools, equipment, and machines of a specialized company. Furthermore, branches were pruned with curved pole pruner Stihl HT 103 saws, and Stihl MS 260 chainsaws.

Two lifting machines were used in the tree pruning operations: (1) a Snorkel Uno41 articulated boom lift with a Kubota V1200 motor (Figure 1a), and (2) a Freightliner M2 106 truck mounted boom lift with a Caterpillar 3126 7.2L motor (Figure 1b). These machines were used to elevate operators to different working heights (Table 1), which also required different extensions of the lifting arm and machine base position in relation to the trees and the environmental elements such as roads, sidewalks, other trees, and buildings.

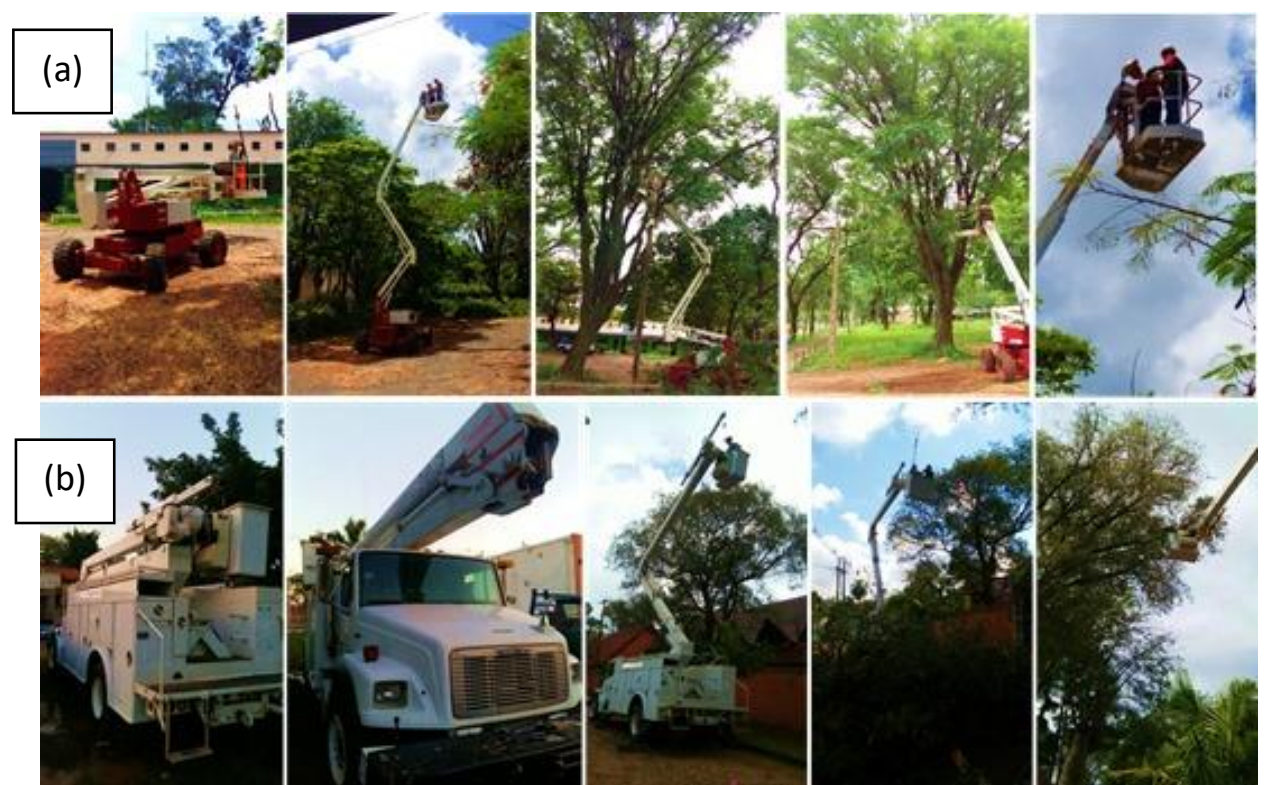

Figure 1. Articulated boom lift (a) and truck mounted boom lift (b) used in urban tree pruning operation.

Figura 1. Plataforma articulada (a) e montada em caminhão (b) usadas na operação de poda urbana de árvores.

FLORESTA, Curitiba, PR, v. 51, n. 2, p. 476-483 abril/jun 2021 
Table 1. Technical specifications of the aerial work platforms.

Tabela 1. Especificações técnicas das plataformas de trabalho aéreo.

\begin{tabular}{|c|c|c|c|c|}
\hline \multirow{2}{*}{ Machine } & \multicolumn{4}{|c|}{ Technical specifications } \\
\hline & General & & Particularity & \\
\hline \multirow{14}{*}{$\begin{array}{l}\text { Articulated boom } \\
\text { lift }\end{array}$} & Brand & Snorkel & & \\
\hline & Model & Uno41 & & \\
\hline & Origin & U.S.A. & & \\
\hline & & Traction & $4 \times 4$ & Hydraulic drive \\
\hline & & Motor & Brand & Kubota \\
\hline & & & Model & V1200 \\
\hline & & & Cylinders & 4 cylinders in line \\
\hline & & & Power & $24 \mathrm{hp}$ \\
\hline & & Swing-arm & Brand & Snorkel \\
\hline & & & Activation & Hydraulic \\
\hline & & & Superstructure rotation & $360^{\circ}$ non-continuous \\
\hline & & Basket capacity & Brand & Snorkel \\
\hline & & & Capacity & 2 men \\
\hline & & & Support capacity & $227 \mathrm{~kg}$ \\
\hline \multirow{18}{*}{$\begin{array}{l}\text { Truck mounted } \\
\text { boom lift }\end{array}$} & Brand & Freightliner & & \\
\hline & Model & M2 106 & & \\
\hline & Origin & U.S.A. & & \\
\hline & & Traction & $4 \times 2$ & \\
\hline & & Motor & Brand & Caterpillar \\
\hline & & & Model & $31267.2 \mathrm{~L}$ \\
\hline & & & Cylinders & 6 cylinders in line \\
\hline & & & Power & 184 kW (250 cv) \\
\hline & & Transmission & Brand & Allison \\
\hline & & & Activation & Automatic \\
\hline & & Swing-arm & Brand & Altec \\
\hline & & & Model & AM60 \\
\hline & & & Origin & U.S.A. \\
\hline & & & Activation & Hydraulic \\
\hline & & & Rotation & Continuous \\
\hline & & Basket capacity & Model & Two Men w/ Dual \\
\hline & & & Capacity & 2 men \\
\hline & & & Support capacity & $272 \mathrm{~kg}$ \\
\hline
\end{tabular}

Source: Data obtained from the machine catalogues.

In order to evaluate these machines, three lifting arm and working platform motion levels $(1,2$, and 3$)$ were examined through a range of general working envelopes (GWE), in which the vertical height was associated with the horizontal extension distance and combined with the rotor's basal rotation to provide the working route (Figure 2). Sampling consisted of 78 selected trees which consumed 136.8 hours of pruning, in which $53.5 \mathrm{~h}$ were performed by the articulated boom lift and $83.3 \mathrm{~h}$ for the truck mounted boom lift. These data corresponded to the time recorded by each machine's hour-meter.

The sample includes different tree species and different ages in the urban area, and the number of pruned branches varies between trees given their location; therefore, these 78 trees were selected to ensure that the samples would be homogeneous and representative to compare the equipment under analysis. Thus, the trees were stratified according to their crown size and volume into three pruning types corresponding to the assessed motion levels, being: crown raising, crown thinning, and crown reduction, corresponding to movements 1,2 and 3 , respectively (Figure 3).

Filming was conducted with cameras mounted on a tripod and on the safety helmet of the operation supervisor to evaluate the pruning operations. At the same time, fuel, lubricant, and other resource usage were collected according to methods described below. Next, time and motion studies and percentage participation of work cycle operational elements were performed by video observations.

Work cycle elements in the urban tree pruning operation were: machine shifting and positioning (SP), platform climb (PC), arm rotation (AR), pruning by machine base without motion (PR), platform descent (PD), telescope contraction (TC) only for the articulated boom lift, and machine anchorage and suspension (AS) only for the truck mounted boom lift.

FLORESTA, Curitiba, PR, v. 51, n. 2, p. 476-483 abril/jun 2021. 
(a) Articulated boom lift

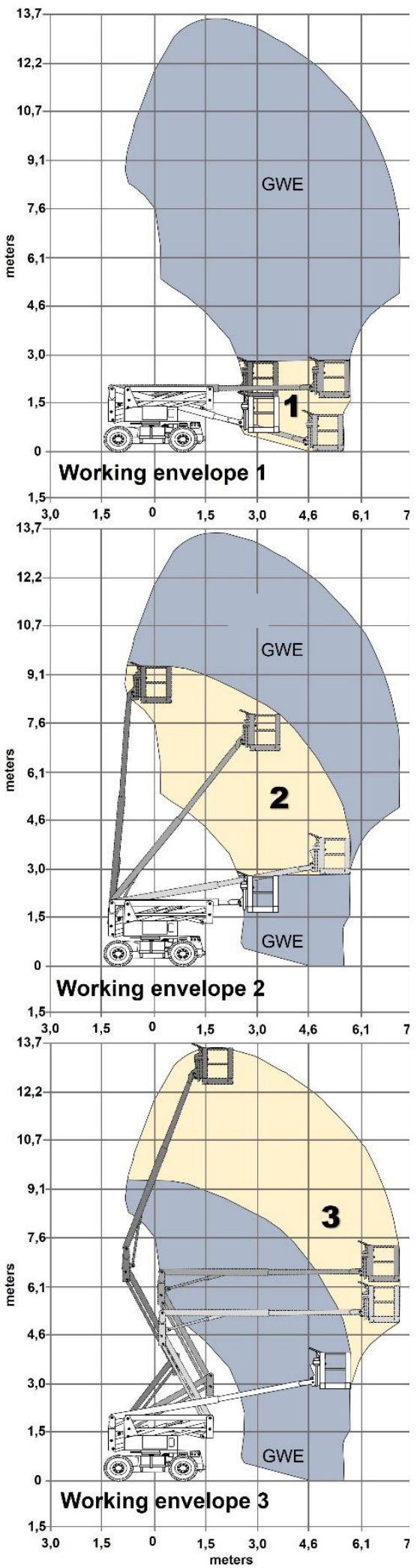

(b) Truck mounted boom lift
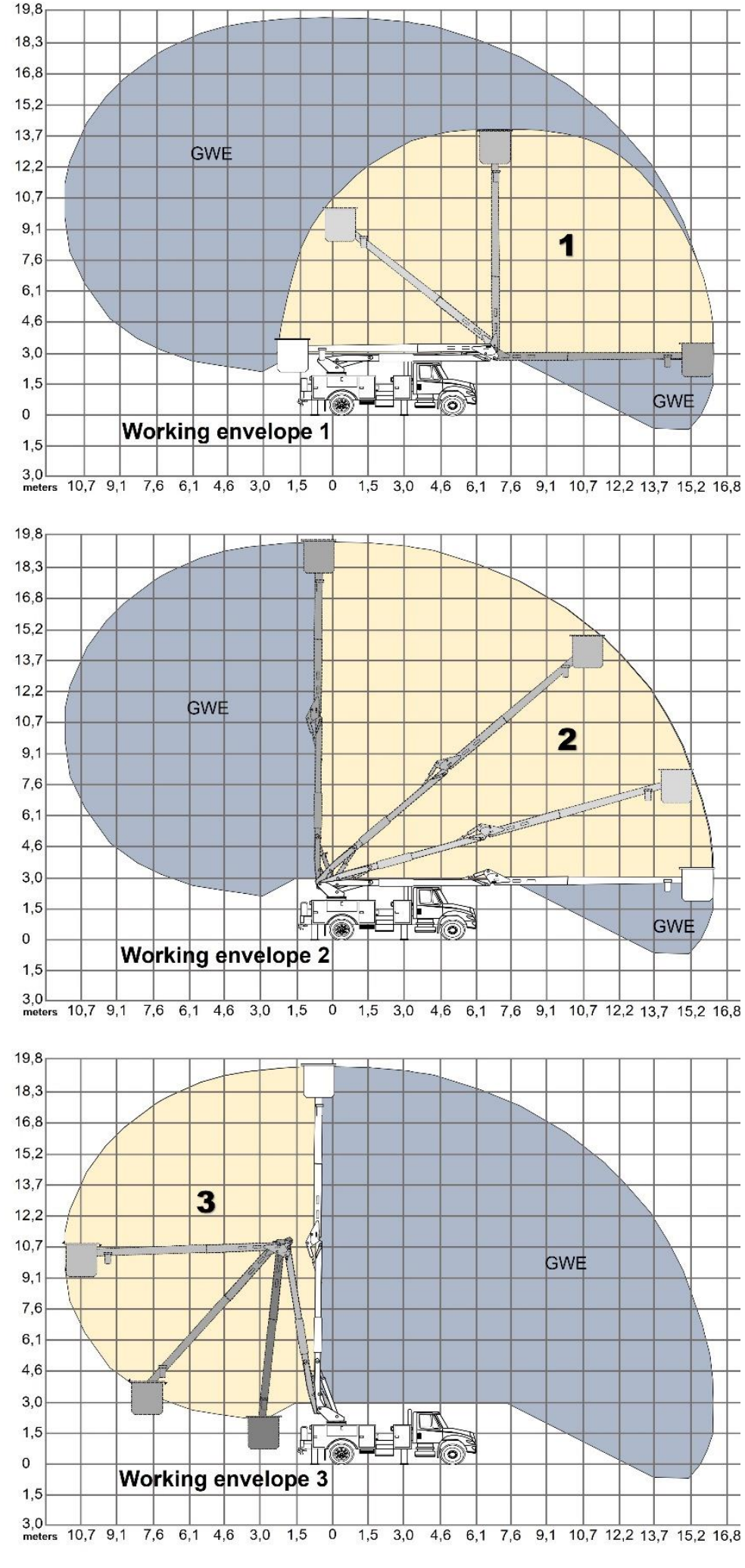

Figure 2. Diagrams of the machines' working envelopes levels $(1,2$, and 3 ) in urban tree pruning operation with (a) an articulated boom lift and (b) a truck mounted boom lift.

Figura 2. Diagramas dos níveis de envelopes de trabalho das máquinas (1, 2 e 3 ) na operação de poda urbana de árvores com plataforma articulada (a) e plataforma montada em caminhão (b).

FLORESTA, Curitiba, PR, v. 51, n. 2, p. 476-483 abril/jun 2021 


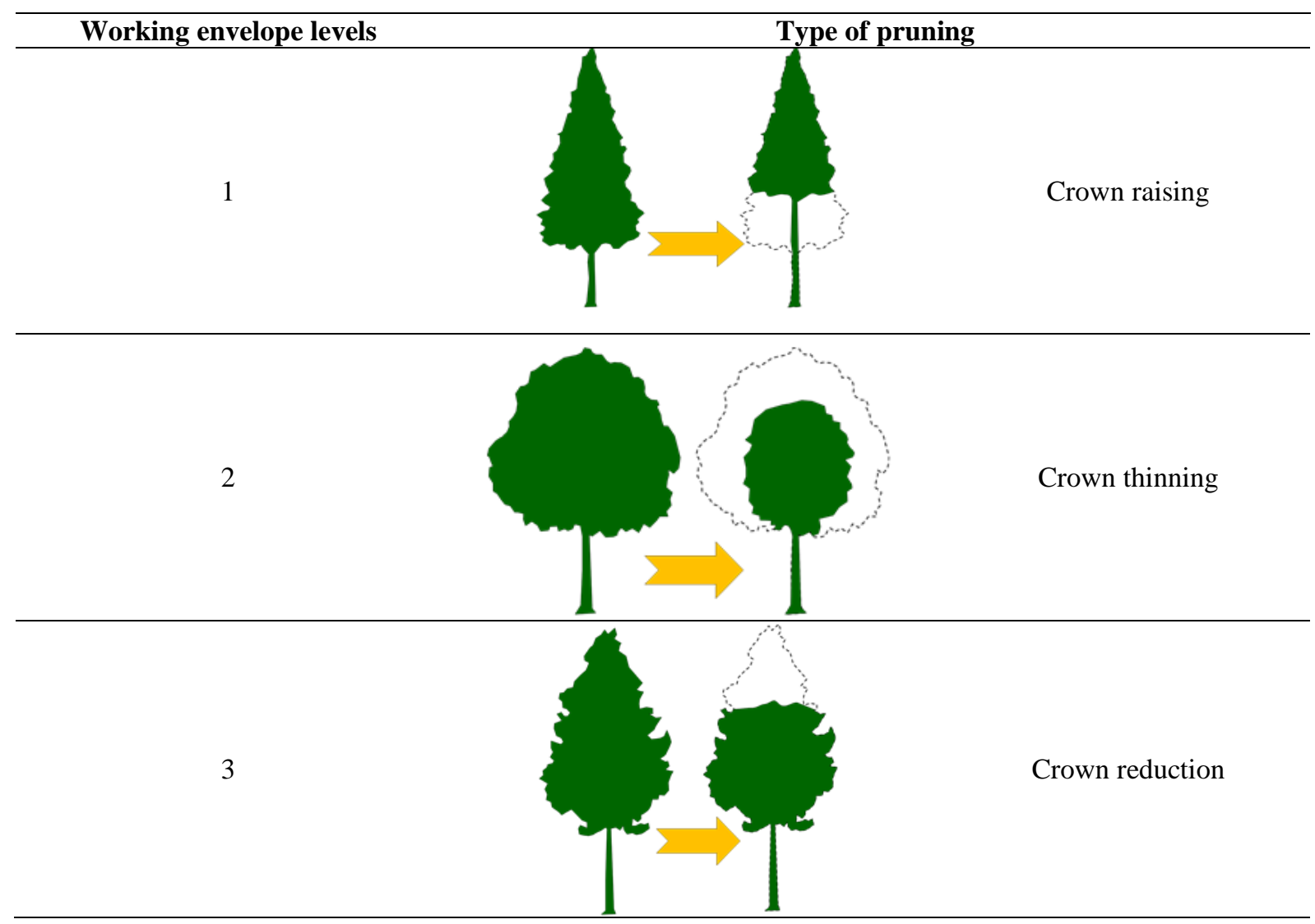

Figure 3. Pruning types. Branches removed are in white. Cuts were made where indicated with dotted lines.

Figura 3. Tipos de poda. Os galhos removidos estão em branco. Os cortes foram feitos onde indicado com linhas pontilhadas.

The operational efficiency (OE) was obtained by equation (1) described by Simões and Fenner (2010) to indicate the percentage of effective working hour by programmed work time.

$$
\mathrm{OE}=\frac{\mathrm{EH}}{\mathrm{TT}} \times 100
$$

In which: OE is operational efficiency (\%), EH is effective working hour, and TT is total programmed work time.

Fuel consumption (FC) was measured by the difference between a full tank before the pruning operation and working day end. Replenishment and service life requirements were monitored for lubricants and greases considering the fluid replacement level in maintenance. These mean values were submitted to the Analysis of Variance and compared by the Tukey test $(\alpha=0.05)$.

In addition, operational cost (OC) was determined on three working envelope levels (Figure 1), according to the methods described by Miyata (1980) and expressed in US dollars (UDS). Operating cost was composed by fixed (depreciation, interest, and insurance), variables (maintenance, fuel, lubricants, grease, and tires), and personnel costs (salary and remuneration).

\section{RESULTS}

Most of the time was consumed in pruning activity with the machine base not moving (Figure 4). Moreover, we noticed an increase in the time consumed with platform climb (PC) and platform descent (PD) elements according to the working envelope levels.

The fuel consumption increased with the motion level by means of the operational efficiency of 86.2 and $76.8 \%$ for the articulated boom lift and truck mounted boom lift, respectively, and was higher in the truck mounted boom lift, from 7.33 to $9.33 \mathrm{~L} \mathrm{~h}^{-1}$ of diesel fuel, than for the articulated boom lift, from 2.58 to $5.22 \mathrm{~L} \mathrm{~h}^{-1}$ (Table 2).

FLORESTA, Curitiba, PR, v. 51, n. 2, p. 476-483 abril/jun 2021 
(a) Articulated boom lift
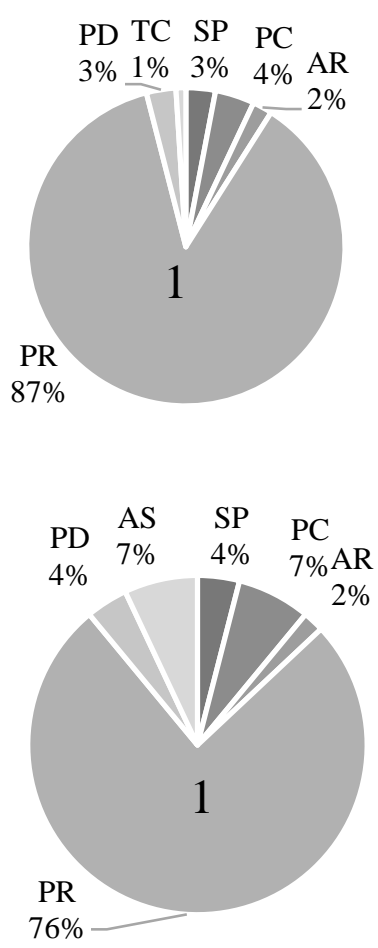

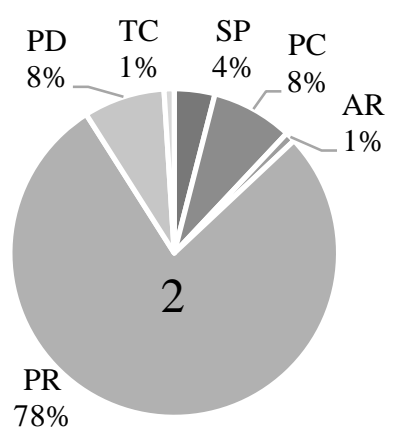

(b) Truck mounted boom lift

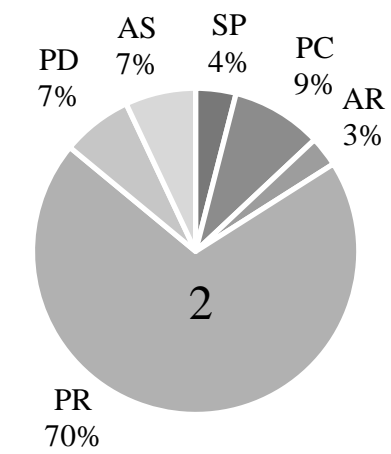

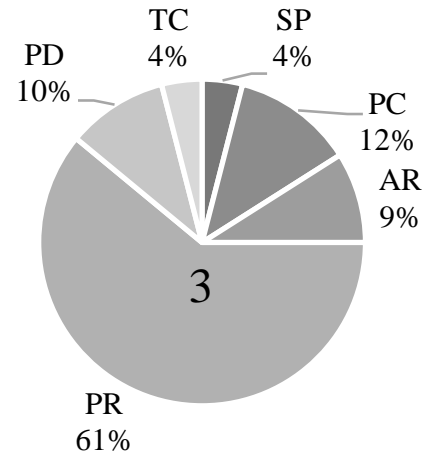

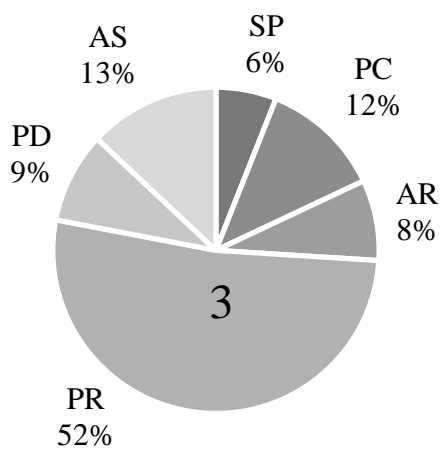

In which: SP is machine shifting and positioning, $\mathrm{PC}$ is platform climb, AR is arm rotation, $\mathrm{PR}$ is pruning on base machine without motion, PD is platform descent, TC is telescope contraction in articulated boom lift, and AS is machine anchorage and suspension in truck mounted boom lift.

Figure 4. Working cycle elements in three working envelopes levels of an urban tree pruning operation with (a) an articulated boom lift and (b) a truck mounted boom lift.

Figura 4. Elementos do ciclo de trabalho em três níveis de envelopes de trabalho da operação de poda urbana de árvores com plataforma articulada (a) e plataforma montada em caminhão (b).

Operating cost for each machine in urban tree pruning increased with motion level. However, operating costs in the truck mounted boom lift presented higher values, between 17.11 and $18.93 \mathrm{USD} \mathrm{h}^{-1}$ (per worked hour), than the articulated boom lift, from 10.28 to $12.56 \mathrm{USD} \mathrm{h}^{-1}$.

Table 2. Operational efficiency (OE), fuel consumption (FC), and operating cost (OC) in an urban tree pruning operation.

Tabela 2. Eficiência operacional (OE), consumo de combustível (FC) e custo operacional (OC) na operação de poda de árvores urbanas.

Articulated boom lift

Truck mounted boom lift

\begin{tabular}{|c|c|c|c|c|c|c|}
\hline & $\begin{array}{l}\text { OE } \\
(\%)\end{array}$ & 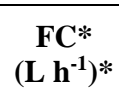 & $\begin{array}{c}\text { OC }^{* *} \\
\left(\mathrm{USD} \mathrm{h}^{-1}\right)\end{array}$ & $\begin{array}{c}\text { OE } \\
(\%)\end{array}$ & $\begin{array}{c}\mathbf{F C}^{*} \\
\left(\mathbf{L ~ h}^{-1}\right)\end{array}$ & $\begin{array}{c}\text { OC } \\
\left(\mathrm{USD} \mathrm{h}^{-1}\right)\end{array}$ \\
\hline 1 & 86.0 & $2.58 \mathrm{a}$ & 10.28 & 77.9 & $7.33 \mathrm{a}$ & 17.11 \\
\hline 2 & 87.1 & $4.34 \mathrm{~b}$ & 11.74 & 76.9 & $8.22 \mathrm{ab}$ & 17.92 \\
\hline 3 & 85.5 & $5.22 \mathrm{c}$ & 12.56 & 75.6 & $9.33 \mathrm{bc}$ & 18.93 \\
\hline Mean & 86.2 & 4.0 & 11.5 & 76.8 & 8.3 & 18.0 \\
\hline
\end{tabular}

* values followed by the same letter did not differ statistically by the Tukey test $(\mathrm{p} \leq 0.05)$.

** cost of machine's movement on the road was not included.

\section{DISCUSSION}

Some studies have been conducted to report the maintenance costs of urban trees (ESCOBEDO et al., 2008; LEAL et al., 2008; VOGT et al., 2015; SONG et al., 2018). However, there is a lack of knowledge about

FLORESTA, Curitiba, PR, v. 51, n. 2, p. 476-483 abril/jun 2021 
new machines for urban tree pruning, especially on aerial work platforms. Therefore, the results of this study are important to provide useful information for decision-making in urban tree management.

An aerial work platform must generally be used safely to prevent accidents (TORIBIO et al., 2010). In this study, pruning was performed through platforms established at points which allowed access to tree branches, aiming to avoid contact between workers and machines with falling branches and mitigate the accident risk (BORTOLINI et al., 2016; Cal/OSHA, 2016; ANDERSON, 2010; NIOSH, 1992). Thus, in order to achieve this requirement, the machines' work was reduced to stabilize the entire device and static positioning after moving and positioning required basic operation of the motor power supply at different acceleration levels due to the work force transmission (KRASUCKI et al., 2009).

However, the machines' work positioning requires a complete combination of the machine base and articulated lifting arm, in which the operating times of these activities differ according to the tree pruning height. Therefore, we observed an increase in the time consumed in relation with dynamic activities such as climbing and descending platforms, in the working envelope levels (Figure 4).

Increased lifting arm motion in the highest range of motion level influenced the operating costs (JINQUAN et al. 2016) (Table 2). This result indicates that it is possible to combine working envelope levels for planning urban tree pruning operations, aiming toward reducing fuel consumption and costs in pruning performed at the smallest heights.

Although the truck mounted boom lift presented the highest fuel consumption to power the hydraulic system, it resulted in statistically different mean values between working envelope levels (Table 2) due to the machine's displacement between trees. Therefore, auxiliary power sources or hybrid motors may be proposed for use in the motion and stabilization of aerial work platform in order to reduce fuel consumption (KRASUCKI $e t$ al., 2009; USDE, 2017).

Although fuel consumption levels and operating costs in the articulated boom lift were very adequate in this study (Table 2), we have pointed out that the cost of the machine's movement on the road was not included in fuel consumption. The displacement and cost could be a difference in the selection of the machine to employ because the articulated boom lift needs to have a board truck for transportation. In addition, it should be considered that the truck mounted boom lift cannot leave the road to operate. Therefore, future works may include additional logistics costs for comparison with the truck mounted boom lift.

\section{CONCLUSIONS}

- The articulated boom lift and truck mounted boom lift evaluated in an urban tree pruning operation herein presented different operating costs which increase with highest range of motion level;

- The main reason is the engine operation intensification and energy expenditures required by the machines' hydraulic system, especially for the truck mounted boom lift, with influence on the increase in fuel consumption and is characterized as the main variable which affects the machines' operations in different motion levels.

\section{REFERENCES}

ANDERSON, D. Mobile lift and chipper unit. United States Patent No: US 2010/0193620 A1. The United States Patent and Trademark Office, 2010. 7 p.

BORTOLINI, L.; CIVIDINO, S. R. S.; GUBIANI, R.; CECCHINI, M.; DELFANTI, L. M. P.; COLANTONI, A. Urban green spaces activities: A preparatory groundwork for a safety management system. Journal of Safety Research, v. 56, p. 75-82, 2016.

CAL/OSHA (Consultation Services Branch Division of Occupational Safety and Health). Tree Work Safety Guide. 2016, 19 p.

DOBBS, C.; ESCOBEDO, F. J.; ZIPPERER, W. C. A framework for developing urban forest ecosystem services and goods indicators. Landscape and Urban Planning, v. 99, n. 3/4, p. 196-206, 2011.

DUJESIEFKEN, D.; STOBBE, H. The Hamburg tree pruning system: A framework for pruning of individual trees. Urban Forestry \& Urban Greening, v. 1, n. 2, p. 75-82, 2002.

ESCOBEDO, F. J.; WAGNER, J. E.; NOWAK, D. J.; MAZA, C. L.; RODRIGUEZ, M.; CRANE, D. E. Analyzing the cost effectiveness of Santiago, Chile's policy of using urban forests to improve air quality. Journal of Environmental Management, v. 86, n. 1, p. 148-157, 2008.

FIEDLER, N. C.; SONE, E. H.; VALE, A. T.; JUVÊNCIO, J. F.; MINETTE, L. J. Tree pruning accident risk

FLORESTA, Curitiba, PR, v. 51, n. 2, p. 476-483 abril/jun 2021 
assessment in urban landscaping of the Federal District - Brazil. Revista Árvore, Viçosa, v. 30, n. 2, p. 223-233, 2006.

FINI, A.; FRANGI, P.; FAORO, M.; PIATTI, R.; AMOROSO, G.; FERRINI, F. Effects of different pruning methods on an urban tree species: A four-year-experiment scaling down from the whole tree to the chloroplasts. Urban Forestry \& Urban Greening, v. 14, n. 3, p. 664-674, 2015.

JINQUAN, G.; HONGWEN, H. ;CHAO, S. Analysis of the performance of aerial work platform working device based on virtual prototype and finite element method. Energy Procedia, v. 104, p. 568-573, 2016.

KOTTEK, M.; GRIESER, J.; BECK, C.; RUDOLF, B.; RUBEL, F. World map of the Köppen-Geiger climate classification updated. Meteorologische Zeitschrift, v. 15, n. 3, p. 259-263, 2006.

KRASUCKI, J.; ROSTKOWSKI, A.; GOZDEK, L.; BARTYŚ, M. Control strategy of the hybrid drive for vehicle mounted aerial work platform. Automation in Construction, v. 18, n. 2, 130-138, 2009.

LEAL, L.; BIONDI, D.; ROCHADELLI, R. The implantation and maintenance costs of urban street trees in Curitiba, PR. Revista Árvore, Viçosa, v. 32, n. 3, p. 557-565, 2008.

LOPES, E. S., OLIVEIRA, F. M., MALINOVSKI, J. R., SILVA, R. H. Biomechanic evaluation of workers at the manual and semimechanized pruning activities in Pinus taeda. Floresta, Curitiba, v. 43, n. 1, p. 9-18, 2013.

MIYATA, E. Determining fixed and operating costs of logging equipment. USDA Forest Service, Washington, 1980.

NATH, T. K.; HAN, S. S. Z.; LECHNER, A. M. Urban green space and well-being in Kuala Lumpur, Malaysia. Urban Forestry \& Urban Greening, v. 36, p. 34-41, 2018.

NIOSH (The National Institute for Occupational Safety and Health). Preventing Falls and Electrocutions during Tree Trimming, 1992.

PARAGUAY, 2015. Ley no 4928 de 5 de Marzo de 2015. De protección al arbolado urbano. Available at: http://www.bacn.gov.py/archivos/3090/20150305120616.pdf. Accessed in: December 10th 18.

PRIESTLEY, R.; YOUNG, P.; BUSCH, B. Aerial work platform boom having ground and platform controls linked by a controller area network. United States Patent No: US 6,405,114 B1. The United States Patent and Trademark Office, 2002. $74 \mathrm{p}$.

SIMÕES, D.; FENNER, P. T. Influence of relief in productivity and costs of harvester. Scientia Forestalis, v. 38, n. 85 , p. $107-114,2010$.

SONG, X. P.; TAN, P. Y.; EDWARDS, P.; RICHARDS, D. The economic benefits and costs of trees in urban forest stewardship: A systematic review. Urban Forestry \& Urban Greening, v. 29, p. 162-170, 2018.

TORIBIO, J.; KHARIN, V.; AYASO, F.J.; GONZÁLEZ, B.; MATOS, J.C.; VERGARA, D.; LORENZO, M. Failure analysis of a lifting platform for tree pruning. Engineering Failure Analysis, v. 17, n. 4, p. 739-74, 2010.

USDE - US Department of Energy. Energy efficiency \& renewable energy. Clean Cities: Idling Reduction, USDE, Washington, 2017.

VERDADE, M. A. L.; SZELEST, T. R. Análise quali-quantitativa da arborização no Campus da Universidade Evangélica do Paraguai, localizada no município de Lambaré - PY. Revista Gestão, Sustentabilidade e Negócios, v. 1, n. 1, p. 110-148, 2013.

VOGT, J.; HAUER, R. J.; FISCHER, B. C. The costs of maintaining and not maintaining the urban forest: a review of the urban forestry and arboriculture literature. Arboriculture \& Urban Forestry, v. 41, n. 6, p. 293-323, 2015.

ZILLMER, R. E.; BOEDER, J. L.; GENICH, K. G. A productivity system for tree climbing training. Journal of Arboriculture, v. 26, n. 2, p. 97-105, 2000. 